\title{
1. Democracy: contested concept with a common core
}

\author{
Svend-Erik Skaaning
}

It is well known that democracy means rule by the people. Although this understanding goes all the way back to Ancient Greece (Cartledge, 2018; Dunn, 2005; Held, 2006), democracy has also been construed as a contested concept par excellence (Collier, Hidalgo and Maciuceanu, 2006; Gallie, 1956, p. 169). This special status as an essentially contested concept, which increases temptations to manipulate and abuse the concept, was captured well by George Orwell (1962, p. 149), when in 1946 he made the following statement:

In the case of a word like democracy, not only is there no agreed definition, but the attempt to make one is resisted from all sides. It is almost universally felt that when we call a country democratic we are praising it: Consequently the defenders of every kind of regime claim that it is a democracy, and fear that they might have to stop using the word if it were tied down to any one meaning. Words of this kind are often used in a consciously dishonest way. That is, the person who uses them has his own private definition, but allows his hearer to think he means something quite different.

Systematic accounts of the concept in political theory are to a larger degree constrained by academic standard requirements about consistency and justification. They generally regard freedom and equality as the primary values associated with democracy ${ }^{1}$ (Hansen, 1989; Kelsen, 1920; Munck, 2016), but these concepts are themselves debated. When it comes to democracy, the ways in which citizens should be equal, what freedoms are required - and to which extent equality and freedom need to be fulfilled - are not self-evident.

At a lower level of abstraction, a wide variety of attributes have been associated with the concept of democracy. These include, for example, free and fair elections, freedom of expression, checks and balances, rule of law, civil society engagement, public deliberation, political consensus, majority rule, and economic equality. Whereas some of these features tend to go hand in hand, theoretically and/or empirically, others do not and may even stand in contrast to each other. Consequently, it matters a great deal for our understanding of the relationship between democracy and, say, development, elements that are seen as constitutive of democracy, and that are conceived as potential causes and consequences of democracy.

A clear understanding of what is meant by democracy is warranted for several reasons. It is important to have a clear understanding of key concepts when developing and evaluating theoretical arguments and to justify why and how the chosen definition fits the particular research agenda. Moreover, any attempt to operationalize democracy for the purpose of empirical investigation depends upon a particular understanding of the concept. Since there are multiple conceptions of democracy (see Cunningham, 2002; Held, 2006; Naess, Christophersen and Kvalo, 1956), most of which resonate in some fashion with the core meaning of rule by the people (Coppedge et al., 2011; Møller and Skaaning, 2011, 2013), the need for making a motivated, explicit choice is all the more obvious. This choice might not satisfy everyone, but transparency will at least enable systematic use and scrutiny. 
Table $1.1 \quad$ Values and criteria linked to different conceptions of democracy

\begin{tabular}{|c|c|c|}
\hline & Principal Value & Features \\
\hline Electoral democracy & $\begin{array}{l}\text { Popular sovereignty achieved through } \\
\text { contested elections filling legislative and } \\
\text { (directly or indirectly) executive offices }\end{array}$ & $\begin{array}{l}\text { Free and frequent elections } \\
\text { Government responsible to the electorate (universal } \\
\text { adult suffrage, freedom of expression, freedom of } \\
\text { association) }\end{array}$ \\
\hline Liberal democracy & $\begin{array}{l}\text { Guaranteed individual liberty understood } \\
\text { as freedom from state repression }\end{array}$ & $\begin{array}{l}\text { Civil rights and liberties, checks and balances, rule of } \\
\text { law }\end{array}$ \\
\hline Egalitarian democracy & Equal political empowerment & $\begin{array}{l}\text { Equal distribution of resources, no discrimination, equal } \\
\text { access to agenda setting and decision making }\end{array}$ \\
\hline Participatory democracy & $\begin{array}{l}\text { Direct, active participation of all in every } \\
\text { stage and level of political decision } \\
\text { making }\end{array}$ & $\begin{array}{l}\text { Civil society engagement, high turnout, strong local } \\
\text { democracy, opportunities of political involvement, } \\
\text { including direct decision making }\end{array}$ \\
\hline Deliberative democracy & $\begin{array}{l}\text { Political agenda setting and decision } \\
\text { making based on well-informed and } \\
\text { reasoned justification }\end{array}$ & $\begin{array}{l}\text { Public and respectful deliberations and consultative } \\
\text { bodies, focus on facts and the broader societal } \\
\text { implications of policies in deliberations and decision } \\
\text { making }\end{array}$ \\
\hline Majoritarian democracy & $\begin{array}{l}\text { Efficient decision making reflecting the } \\
\text { will of the majority }\end{array}$ & Power-concentrating institutions \\
\hline Consensual democracy & $\begin{array}{l}\text { Inclusive decision making involving and } \\
\text { pleasing a broad range of opinions }\end{array}$ & Power-dispersing institutions \\
\hline
\end{tabular}

In this chapter, I first present some predominant conceptions of democracy. Although the number of particular meanings associated with the concept of democracy is legion (see Collier and Levitsky, 1996), my reading of the voluminous literature on the subject suggests the existence of seven main traditions, that is, electoral democracy, liberal democracy, egalitarian democracy, participatory democracy, deliberative democracy, majoritarian democracy and consensual democracy. Table 1.1 provides an overview of the respective values and distinguishable features associated with them, which are described in the above table.

Taken together, these conceptions offer a relatively comprehensive account of how democracy has been used in academic debates in recent decades (Coppedge et al., 2011). Different understandings emphasize distinct values and institutions. Yet, they also tend to share a common core in the form of free elections, as is clear from the presentation of the different principles of democracy in the first part of the chapter. ${ }^{2}$

In the second part of this chapter, I briefly present two different approaches to systematize the relationship between some of these ideal typical constructions. The first attempts to separate as much as possible the defining aspects, which go beyond the electoral core (see Coppedge et al., 2020). The second suggests a cumulative ordering of these features, moving from a relatively undisputed core (a thin conception) to increasingly comprehensive definitions (thicker conceptions) by the stepwise addition of - increasingly disputed - features (see Møller and Skaaning, 2011). Both these approaches are put to work in the third part of the chapter, in which I provide some empirical overviews where various measures of democracy are used to categorize contemporary polities. 


\section{ELECTORAL DEMOCRACY3}

\section{The Schumpeterian Version - Minimalist Democracy}

The electoral principle of democracy focuses on the role of contested elections as the principal means to winning political power. Joseph A. Schumpeter ([1942] 1974) famously presented a minimalist, procedural understanding of democracy. In opposition to idealist and comprehensive conceptions of democracy, he emphasizes that a definition of democracy should preferably be narrow and realistic and that the democratic principle only implies that government power should rest with the group who wins a larger popular backing than their political opponents (ibid., p. 272).

Democracy thus merely concerns elections, that is, it is a matter of the selection of political leadership, and the primary role of the electorate is to take part in the elections that appoint the members of the legislature and - directly or indirectly - the executive. Accordingly, Schumpeter (ibid., p. 269) defines democracy in the following way: 'The democratic method is that institutional arrangement for arriving at political decisions in which individuals acquire the power to decide by means of a competitive struggle for the people's vote.' This means that in a democratic regime, leaders are selected by a broad electorate through contested elections held periodically. These are the principal tools to achieve the overall goal of popular sovereignty. The political competition empowers popular rule by fulfilling three criteria: those winning the elections take government power; the government is not removed by undemocratic means and core democratic institutions, first and foremost the parliament, operate continuously; and elections are held on a relatively frequent basis (see also Przeworski et al., 2000, Ch. 1). It deserves explicit mentioning that Schumpeter's understanding of democracy does not require universal suffrage or respect for civil liberties such as the freedoms of expression, assembly, and association.

\section{The Dahlian Version - Polyarchy}

Together with Schumpeter's minimalist definition of democracy, Robert A. Dahl's (1971, 1989, 1998) concept of polyarchy has established itself as a standard reference in debates within political science about the meaning of democracy (Collier and Levitsky, 1997, p. 431). The Schumpeterian and Dahlian conceptions have been especially influential in studies with broad empirical ambitions.

Dahl (1989, pp. 108-14) reserved the term democracy for political processes fulfilling a much more demanding set of criteria, which will probably never be realized by any polity: effective participation, voting equality when decisions are made, enlightened understanding, ${ }^{4}$ control of the agenda, and inclusive citizenship. Yet, he also introduced the supplementary concept of polyarchy, which can be understood as a definition of electoral democracy somewhat more demanding than Schumpeter's.

The concept of polyarchy thus also highlights free elections as essential for democracy and focuses on procedures and institutions. However, in contrast to Schumpeter, Dahl includes universal suffrage and freedom of expression and association among the defining attributes. Universal adult suffrage is key to him because of equal recognition of citizens as capable of pursuing their own interest in connection with collective decision making (Dahl, 1989, p. 105). 
Moreover, respect for a number of civil liberties is needed to enable the exchange of ideas and collective mobilization. On the one hand, these rights support electoral contestation. On the other hand, they enable the population to control elected officials between the elections. Hence, democracy requires not only free, fair, and contested elections, but also the liberties such as freedom of expression and freedom of association that make them meaningful (see Diamond, 2002, p. 21).

The result of Dahl's reflections on the topic is a list of $\operatorname{six}^{5}$ institutional guarantees, which together defines polyarchies (Dahl, 1998, pp. 85-6):

1. Elected officials: control over government decisions is constitutionally vested in officials elected by citizens, which means that the government is representative.

2. Free, fair, and frequent elections: elected officials are chosen in frequent and fairly conducted elections in which coercion is comparatively uncommon.

3. Freedom of expression: citizens have the right to express themselves on political matters without facing the danger of severe punishment.

4. Alternative information: citizens have the right to seek alternative and independent sources of information, which are legally protected and not under political control.

5. Associational autonomy: citizens have the right to form relatively independent associations or organizations in order to exercise their rights.

6. Inclusive citizenship: no adult who permanently resides in the state and is subject to its laws can be denied the rights that are available to others and necessary to the other political institutions.

\section{Contested Elections as a Prerequisite of Democracy}

The attributes associated with electoral democracy arguably have a special status compared to those added by other conceptions of democracy. In short, the minimal conditions constitute the sine qua non of democracy (Collier and Adcock, 1999, p. 599; Coppedge et al., 2011; Merkel, 2004, pp. 36-8). This means that we should not call a political regime democratic if contested elections do not determine access to political power (unless the polity is characterized by direct democracy).

Accordingly, it was conceptual stretching (see Sartori, 1970) when Trujillo spoke of the Dominican Republic under his dictatorial rule as a neo-democracy; when German Nazis envisaged a Führerdemokratie; when Franco termed his semi-fascist, military regime an organic democracy; when communist leaders in the Eastern Bloc referred to their political regimes as people's democracies; or when President Xi Jinping recently called China a whole-process democracy. In the absence of free elections, a political regime is undemocratic, full stop! Note, furthermore, that this conclusion also applies to the many regimes, which only formally fulfill the criteria for electoral democracy. In this context, multi-party autocracies, which allow opposition parties to run for elections, but where they have no chance of winning in practice due to different sorts of overt and covert manipulation, cannot be called democracies (see, e.g., Levitsky and Way, 2010; Morse, 2012; Schedler, 2013; Seeberg, 2018).

There is broad agreement about disqualifying such regimes from the set of democracies. Some argue, however, that the electoral criteria are insufficient to capture the meaning of democracy. This critique has given rise to additional principles of democracy, each of which is designed to remedy one or more limitations of electoral democracy. The more comprehensive 
conceptions thus complement electoral properties through additional attributes supposed to reflect or support particular values.

\section{LIBERAL DEMOCRACY}

The concept of liberal democracy is one prominent example of a principle of democracy that goes beyond the electoral core. It stresses the intrinsic value of individual liberty understood as protection of individual rights against state repression and unrestricted majoritarian rule. This principle is rooted in the classical liberal tradition that evolved in Europe during the Age of Enlightenment as a reaction to absolutist rule, aristocratic privileges, and clerical dogmas. Liberal ideals include reason, tolerance, pluralism, secularism (or at least freedom of religion), and freedom of choice (Held, 2006, p. 59).

On this basis, the liberal tradition sees the state as a double-edged sword. One the one hand, political institutions are necessary to safeguard individual freedoms. On the other hand, they also pose a direct threat to those freedoms (Holmes, 1995, p. 270). ${ }^{6}$ Accordingly, the power of rulers should be limited. Government authority must be derived from, and limited by, law (Holmes, 1995; O'Donnell, 2007; Ross, 1952; Sartori, 1987, p. 374; Vile, 1998). Constitutional rules should emphasize the protection of civil liberties, constraints on the executive and legislature, and protection of minority rights (Gordon, 1999).

One of the distinguishing features of the liberal principle is the idea of checks and balances among legislative, executive, and judicial powers. This idea was originally conceived by Montesquieu ([1748] 1989) and later adapted by James Madison in connection with the framing of the US Constitution (Hamilton, Madison and Jay, [1787/1788] 1992). Since the executive is the branch of government most prone to abuse, we regard the judicial and legislative branches as providing checks against executive authority. Independent courts also serve the function of adjudicating among citizens and between citizens and public authorities.

Another key feature of liberal democracy is a catalog of individual rights (Beetham, 2004). In addition to the political liberties, already included among Dahl's polyarchy criteria, the liberal principle embraces associated rights such as personal integrity and security, freedom of movement, freedom of religion, and property rights. All these rights may be grouped together under the rubric of civil liberties.

The final feature emphasized by the liberal tradition is the rule of law (O'Donnell, 2004). This requirement implies that there is equality before the law and that the rules need to be general, prospective, clear, certain, and impartially and regularly applied by public authorities (Fuller, 1969; Raz, 1979; see also Møller and Skaaning, 2014). Taken together, civil liberties, checks and balances, and the rule of law may be said to fulfill the liberal ideal insofar as all three impose constraints on state repression and help to secure fundamental rights for citizens.

Note that the liberal model generally takes a negative view of political power. This is the background for the historical suspicion about popular sovereignty among liberals. They basically feared that inclusive elections would undermine individual rights, including property rights (see Held, 2006, Ch. 3; Macpherson, 1977). Gradually, liberal rights fused with the principle of popular rule, however, and created the modern understanding of liberal democracy. This happened in the theoretical works of political thinkers such as Thomas Paine ([1791] 1996), Jeremy Bentham ([1776] 1988), and John Stuart Mill ([1861] 1993). More importantly, it also happened in practice with the emergence of political regimes characterized by free, 
inclusive elections as well as general respect for liberal rights. These empirical developments have tended to disprove the original fears of a trade-off between popular sovereignty and liberal features. Instead, they lend support to the position that the electoral and liberal elements of democracy are better conceived as mutually constitutive (Habermas, [1992] 1996; Merkel, 2004).

\section{EGALITARIAN DEMOCRACY}

The principle of egalitarian democracy is based on the idea that elections (and liberal rights) are insufficient to realize political equality (Beitz, 1990; Lindblom, 1977). To a large extent, the egalitarian perspective on democracy grows out of a leftist critique of electoral and liberal democracy. Some writers in the Marxist tradition merely view free elections as a democratic facade with the hidden purpose to ensure class rule (of the bourgeoisie) rather than political and social equality (e.g., Lenin, [1917] 2004, pp. 73-7; Luxembourg, [1899] 2006; Marx, [1848] 1988). Others hope to integrate electoral democracy with socialist policies to combine the best of both worlds (Bernstein, [1899] 1961); Heller, 1930). To some extent, this tradition resonates with Dahl's $(1982,1985,1989)$ understanding of a fully democratic process mentioned above, as it would require substantial redistribution of politically relevant power resources to reach the goal of political equality.

To be fully democratic, all citizens should de facto possess equal resources that can be marshalled to make self-government real. What is specific about the egalitarian tradition is the emphasis on equal protection of rights across genders and social groups, equal access to positions of political power, and equal distribution of key resources (Ake, 2000). Material as well as immaterial inequalities can fundamentally undermine the exercise of rights and liberties and thus compromise the extent to which rule by the people is realized.

The egalitarian ideal mandates political equality across social groups - as defined by income, wealth, education, ethnicity, religion, caste, race, language, region, gender, sexual identity, or other ascriptive characteristics. Ideally, all groups should enjoy similar capabilities to participate in politics, that is, to vote, to serve in leadership positions, to place issues on the agenda, and to influence policy making in other ways.

A key assumption embedded in this tradition of thought is that political power is associated with social power. If an individual or group is disadvantaged in society, this will likely reflect in the political sphere. Material and immaterial inequalities inhibit the actual use of formal political (electoral) rights and liberties. Hence, for the egalitarian democratic ideal to be achieved, citizens must have equality in power resources within society. In other words, rule by the people requires equality among the people, meaning that people must be substantially equal in wealth, education, and health, and group relationships should be unhindered by social prejudice (Ake, 2000; Meyer, 2007; see also Laclau and Mouffe, 1985).

At a minimum, the distribution of resources must be sufficient to ensure that citizens' basic needs are met in a way that enables their meaningful participation in politics (Beetham, 1999; Saward, 1998). To a large extent, this view aligns with the capability tradition, which understands full development of human capability as both an aim in itself and important for the true realization of democracy (see Nussbaum, 2011; Sen, 2001).

Egalitarian democracy thus requires electoral democracy and liberal rights to be undergirded by equal respect for all social groups and individuals and an equal distribution of resources 
across social groups and individuals - or at least the fulfilment of minimum standards that enable everybody to participate effectively in political processes.

\section{PARTICIPATORY DEMOCRACY}

The key value of participatory democracy is active political participation and direct rule by citizens. It is rooted in the tradition of direct democracy as practiced in Ancient Greece and later envisaged by Jean-Jacques Rousseau (Hansen, 1991; Ober, 1989; Rousseau, [1762] 1984). This model of democracy received renewed attention from scholars in the 1970s and 1980s (e.g., Macpherson, 1977; Mansbridge, 1983; Pateman, 1976), and, recently, activists in many countries have followed by criticizing the functioning of electoral and liberal democracy and making calls for political reforms, which echo some of the principles underlying this tradition.

This ideal is based on the assumption that mere representation by elected politicians is inherently flawed from a democratic perspective. Representation is said to alienate human beings from each other rather than bringing them together, and the basis of electoral and liberal democracy in the form of autonomous citizens casting ballots on election day does not facilitate a strong democracy (see Barber, 1984). Joel Wolfe (1986, p. 10) summarizes this perspective as follows: 'strong [participatory] democracy should be a form of government in which all people participate in decision-making and implementation...participation by all is imperative because it creates shared interests, a common will, and community action, all of which inevitably give legitimacy to politics.' The benefits of active participation are multifold. It is expected to develop public awareness and the capacities of citizens, improving their sense of membership in the community. This may be especially important for groups facing discrimination in society. Moreover, participation will inform the formation of preferences, and citizens gain a sense of ownership over the political process, which increases legitimacy.

Moderate versions of participatory democracy do not reject political representation altogether. However, the institutions associated with electoral democracy need to be undergirded by alternative tools of political engagement and influence to achieve the participatory ideal. Rather than looking solely at the right to elect representatives, the actual turnout at elections is relevant. More importantly, in addition to voting, the polity should provide other mechanisms of citizen participation such as direct democracy (initiatives and referenda), party primaries, a strong and engaged civil society (including demonstrations, protests, and strikes), and significant policy-making power at all levels through participatory budgeting, citizen assemblies/ councils/panels, and so forth. Arguably, these forms of engagement also enhance the quality of representation by reducing the autonomy of politicians from citizens as well the autonomy among citizens.

\section{DELIBERATIVE DEMOCRACY}

Deliberative democracy embraces the core value that political decisions in pursuit of the public good should be informed by respectful and reason-based dialogue rather than by emotional appeals, solidary attachments, self-interests, or coercion. This conception was first conceived and developed into an independent perspective in the early 1980s (see Bessette, 1980; Habermas, [1981] 1987). To a large degree, this was a response to dissatisfaction with 
some unwanted characteristics of political discussion and decision making such as the personalization of politics, disrespect for alternative views, pork-barrel politics, affective appeal to base interests, and narrow-minded pursuit of irrational preferences.

The deliberative principle says that a legitimate political order is one that is justifiable to all members of society. A key objective is to transform political preferences through a process of deliberation. The outcome should be political positions that can withstand public scrutiny (Held, 2006, p. 237). To achieve this aim, more focus has to be directed to the pre-voting communicative processes of opinion formation (Bohman, 1998; Elster, 1998; Gutmann and Thompson, 1996; Habermas, [1992] 1996). Deliberative democracy thus requires more than an aggregation of existing preferences. The process by which decisions are reached is also crucial.

A deliberative process is one in which public reasoning focused on the common good motivates political decisions. Deliberation can basically be understood as 'debate and discussion aimed at producing reasonable, well-informed opinions in which participants are willing to revise preferences in light of discussion, new information, and claims made by fellow participants' (Chambers, 2003, p. 309). It also requires respectful dialogue at all levels - from preference formation to final decision - among informed and competent participants who are open to persuasion (Dryzek, 2010, p. 1). Rational political deliberation more generally has to be "“fact-regarding" (as opposed to ignorant or doctrinaire), "future-regarding" (as opposed to myopic) and "other-regarding” (as opposed to selfish)' (Offe and Preuss 1991, p. 157).

Even though proponents of deliberative democracy vary in their views about the institutions of electoral democracy, many of them think the deliberative features should supplement rather than replace representative democracy (e.g., Chambers, 2003, p. 308; Fishkin, 1991). What is distinct to deliberative democracy is that political decision making must fulfil the criteria of public deliberation and consultation, respectful debate, and reasoned justification with exclusive emphasis on the public good.

\section{MAJORITARIAN VS CONSENSUAL DEMOCRACY}

The idea that the will of the majority of the people should decide policies affecting society is the key value underlying the majoritarian democracy perspective. Democracy is boosted when political institutions ensure that the voice of the many prevail over the few. To facilitate this, political institutions should centralize and concentrate power within the context of electoral democracy, generating an efficient method of decision making and implementation.

Consensual democracy is basically the mirror image of majoritarian democracy, apart from the fact that they share the core of electoral democracy. Accordingly, in order to realize popular rule, the consensual principle prescribes political power to be widely dispersed and political institutions to encourage the inclusion of as many political perspectives as possible in the decision-making process. Decision making should involve and take into account as broad a range of opinions as possible, meaning that all affected groups are to be heard and have an impact on the result. Inclusionary measures should preserve interests even when opposed by the government.

The origin of these contrasting types of democracy may be assigned to Walter Bagehot ([1867] 1963, pp. 219-22), who in the mid-nineteenth century contrasted the British political model with the US political model: 'The English Constitution...is framed on the principle of 
choosing a single sovereign, and making it good; the American, upon the principle of having many sovereign authorities, and hoping that their multitude may atone for their inferiority.' Some decades later, Arendt Lijphart (1999) reinvigorated the debate, and his distinction between consensus and majoritarian democracy has been pointed out as 'the single most influential typology of modern democracies' (Mainwaring, 2001, p. 171). ${ }^{7}$

Broadly speaking, the majoritarian ideal is fulfilled when political institutions are power concentrating, that is, they centralize political power in the hands of a single party and the number of veto points/players are very limited. A veto point may be understood as a constitutional body such as a legislature or a political body such as a political party or interest organization. Such institutional set-up is supposed to strengthen the government and ensure effective decision making, which is advantageous when dealing with complex societal challenges and trying to overcome the resistance of special interests (Freeden, 1978).

While both majoritarian democracy and consensual democracy share a commitment to electoral democracy, the institutions that fulfill the two ideals are directly contrary. According to the consensual principle, political power should be dispersed with the help of many veto points. Considerable power should be delegated to independent bodies at national and subnational levels. Power-sharing is key, so decision making at various levels should be characterized by super-majorities, and executive powers be vested with oversized coalitions.

\section{HOW THE DIFFERENT CONCEPTIONS RELATE TO EACH OTHER}

\section{Orthogonal Components with a Common Core}

One way to view the relationship between different conceptions of democracy is to interpret them as being as distinct as possible apart from the common electoral core. This is the perspective embraced by the Varieties of Democracy project (see Coppedge et al., 2020). This approach distinguishes between a reduced and a comprehensive version for each of the conceptions of democracy, which supplement the electoral basis with additional criteria. The comprehensive versions cover all defining features, while the reduced versions, referred to as components, only include the most unique attributes of that conception compared to the other conceptions. Accordingly, substantial overlaps are avoided between the liberal, egalitarian, deliberative, participatory, majoritarian, and consensual components. In other words, these are designed to be conceptually distinct (even though they may co-vary empirically).

Figure 1.1 presents the different conceptions of democracy and illustrates how distinct principles of democracy, on the one hand, share an electoral core, and, on other hand, can function as separate extensions of the electoral understanding.

This procedure works well when the reduced components are clearly distinct from each other, as in the case of the participatory and liberal principles, including when they stand in contrast to each other, as in the case of the majoritarian and consensual principles. It is more problematic, however, when there are substantial overlaps between the reduced components as they should preferably be mutually exclusive to fit the approach. 


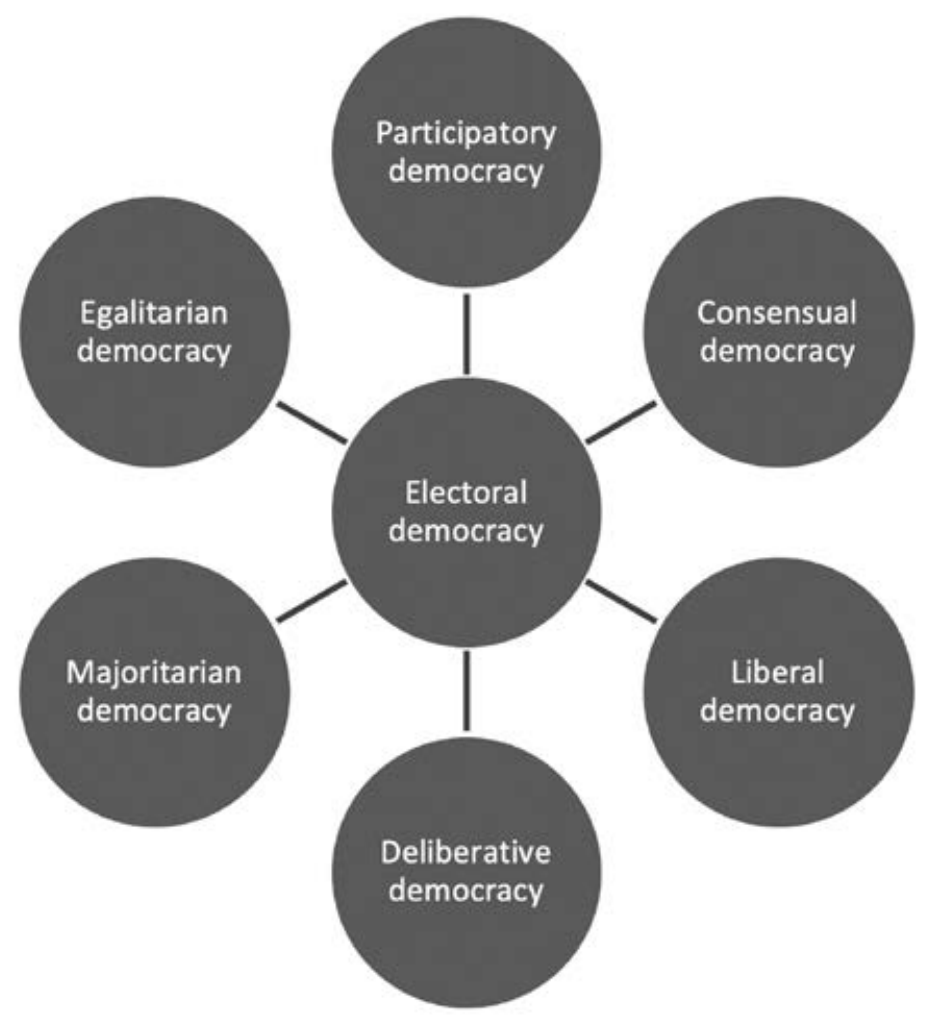

Figure 1.1 Conceptions of democracy

\section{Cumulative Ordering of Components}

One procedure to handle a situation where there is partial overlap between different understandings of democracy is to use the logic of cumulative ordering. However, if one is able to order multiple definitions of democracy in a stepwise fashion, ranging from less demanding, thin versions to more demanding, thick versions, it is possible to construct a hierarchical typology (taxonomy) of conceptions of democracy (see Gerring, Pemstein and Skaaning, 2018; Skaaning, Gerring and Bartusevičius, 2015). This is done by enlisting a sequence of necessary conditions, which at each level are jointly sufficient for a particular understanding of democracy.

This approach cannot be applied to contrasting perspectives or to perspectives that cannot be systematically ordered. This means that some of the principles do not lend themselves to this exercise. However, as shown in Table 1.2, it is possible to do so with the two versions of electoral democracy (i.e., minimalist democracy and polyarchy), liberal democracy, and egalitarian (aka social) democracy (see Møller and Skaaning, 2011, 2013).

The table illustrates the stepwise extension of the definition, where contested elections are necessary for all conceptions but only sufficient for the thinnest type, that is, minimalist 


\begin{tabular}{lcccc}
\hline & $\begin{array}{c}\text { Contested } \\
\text { Elections }\end{array}$ & $\begin{array}{c}\text { Universal Suffrage and Political } \\
\text { Freedoms }\end{array}$ & Liberal Rights & Social Rights \\
\hline Minimalist democracy & + & & & \\
Polyarchy & + & + & + & \\
Liberal democracy & + & + & + & + \\
Egalitarian democracy & + & + & + & + \\
\hline
\end{tabular}

democracy. At the next level, the definitional requirements of polyarchy are captured by adding universal suffrage and political freedoms (free speech and the rights of organization and assembly) to contested elections. Liberal democracy then shares these features but also requires respect for liberal rights in the form of civil liberties and the rule of law, while egalitarian democracy at the highest level combines all the previously listed conditions with respect for social rights.

The logic of this approach entails that the thicker definitions also include the constitutive elements of the thinner definitions. This means that the procedure can handle partial overlaps between the principles; it is even a requirement. The procedure also implies, however, that it is not suitable for principles standing in direct contrast to each other. It also falls short when it is hard to justify why democratic attributes should be arranged in a particular order.

\section{ILLUSTRATIVE CLASSIFICATIONS OF POLITIES}

After the conceptual spadework, it is interesting to see how countries map on to the different categories. This exercise has a two-fold purpose. First, it identifies the closest we get to real-world examples of the types. Second, it gives a raw impression of the empirical variation and distribution. Table 1.3 lists the ten best-performing countries in 2018 according to the Varieties of Democracy (V-Dem) indices constructed to capture exactly the conceptions of democracy described above (see Coppedge et al., 2020). ${ }^{8}$ However, V-Dem does not provide indices for majoritarian democracy and consensus democracy. I therefore employ Lijphart's (1999) classical executives-parties measure to identify the polities, which were most majoritarian and consensual, respectively. His measure covers 1971 to 1996 and offers a single score for each of the 36 electoral democracies included in his study.

The V-Dem indices have been constructed based on the logic of a common overview that shows that it is to a large extent the same countries that do well across the first five conceptions of democracy. This pattern is not self-evident since the construction of these indices has followed the logic of orthogonal components with a common core of electoral democracy described above. This circumstance means that much more variation in the rankings is theoretically possible, especially if there are some trade-offs between the achievement of the various components. However, this does not seem to be the case, as illustrated by the Scandinavian countries, which do well across the board. Electoral integrity, liberal rights, basic equality, political engagement, and public and respectful political debate tend to go hand in hand in these polities. Also, other countries, such as Estonia, Switzerland, and Costa Rica, figure prominently in the rankings. Unsurprisingly, Switzerland and Uruguay, with their frequent 
Table 1.3 Top performers regarding different conceptions of democracy

\begin{tabular}{llllllll}
\hline & Electoral & Liberal & Egalitarian & Participatory & Deliberative & Majoritarian & Consensus \\
& Democracy & Democracy & Democracy & Democracy & Democracy & Democracy & Democracy \\
\hline 1 & Norway & Norway & Norway & Switzerland & Norway & Jamaica & Switzerland \\
2 & Sweden & Sweden & Denmark & Uruguay & Sweden & Bahamas & Finland \\
3 & Estonia & Denmark & Estonia & Denmark & Denmark & Trinidad \& Tobago & Denmark \\
4 & Costa Rica & Estonia & Luxembourg & New Zealand & Switzerland & Barbados & Belgium \\
5 & Denmark & Switzerland & Sweden & Taiwan & Estonia & UK & Israel \\
6 & Uruguay & Costa Rica & Switzerland & Norway & Luxembourg & Botswana & Netherlands \\
7 & Switzerland & Australia & Portugal & UK & Uruguay & New Zealand & Italy \\
8 & UK & Portugal & Belgium & Costa Rica & Costa Rica & Canada & Papua New Guinea \\
9 & Portugal & Netherlands & New Zealand & Slovenia & Portugal & France & Sweden \\
10 & Luxembourg & New Zealand & Finland & Estonia & Netherlands & Malta & Norway \\
\hline
\end{tabular}

Notes: The first five rankings refer to 2018 and are based on the V-Dem indices for electoral democracy, liberal democracy, egalitarian democracy, participatory democracy, and deliberative democracy. The last two ranking refer to 1971-96 and are based on Lijphart's (1999, p. 312) measure of the so-called executives-parties dimension.

use of referenda and strong traditions of subnational democracy and vibrant civil societies, do extraordinarily well regarding participatory democracy.

The top-ten performers in the majoritarian democracy column are quite different. It is mainly populated by the UK and a number of its former colonies that have largely adopted a similar set of political institutions. Accordingly, the UK is often pointed to as a prime example of a majoritarian democracy. Two parties dominate the political arena, the executive dominates the legislature (where the lower house is much stronger than the upper house), the national government dominates local government, and the power to govern is mostly concentrated in a single party. Moreover, the unwritten constitution is flexible, and there is no judicial review of primary legislation. Taken together, there are only few and weak veto players, so it is unlikely that the majority is obstructed from carrying out its preferred policies.

In contrast to the British system, the institutional set-up in Switzerland is often presented as prime example of a consensus democracy. The political arena is characterized by multiple parties (none of them dominant), the relationship between the executive and legislature (divided into two equally strong chambers) is balanced, regions in the federative structure have strong autonomy, and government power is shared by all important parties in a broad coalition, where different (linguistic) groups are represented in proportion to their size. This rather pure version of a consensus democracy is extraordinary. The political institutions of the other states topping the ranking for consensus democracy, including the Scandinavian countries, are less consistent with regard to promoting inclusion and decentralization. On the one hand, corporatism, multi-party coalition governments, and oversize legislative majorities, are more the rule than the exception. On the other hand, Denmark, Norway, and Sweden are unitary states with unicameral legislatures and do not have strong traditions of judicial review.

But how does the distribution of contemporary democracies look if we employ a cumulative ordering of democratic attributes? To answer this question, I first use the competitive elections indicator from the Lexical Index of Electoral Democracy (LIED) (Skaaning et al., 2015) to distinguish autocracies from minimalist democracies. In the next step, minimalist democracies with a score of at least 0.72 on V-Dem's electoral democracy (polyarchy) index are placed in the group of polyarchies. A score of 0.86 on the V-Dem liberal component index then separates out the liberal democracies, while a subsequent criterion of a minimum score of 
Table 1.4 Taxonomic classification of democracies, 2018

\begin{tabular}{llllll}
\hline Minimalist Democracy & & Polyarchy & Liberal Democracy & Egalitarian Democracy \\
\hline Albania & Guinea-Bissau & Mongolia & Argentina & Australia & Austria \\
Armenia & Guyana & Montenegro & Brazil & Barbados & Belgium \\
Bahamas & Haiti & Namibia & Burkina Faso & Belgium & Canada \\
Benin & Honduras & Nepal & Czech Republic & Cape Verde & Denmark \\
Bhutan & Hungary & Nigeria & Greece & Chile & Estonia \\
Bolivia & India & Papua New Guinea & Malta & Costa Rica & Finland \\
Botswana & Indonesia & Paraguay & Panama & Cyprus & France \\
Bulgaria & Iraq & Philippines & Peru & Italy & Germany \\
Burkina Faso & Israel & Poland & Senegal & Jamaica & Iceland \\
Colombia & Kenya & Romania & Slovakia & Lithuania & Ireland \\
Comoros & Kosovo & São Tomé \& Príncipe & Suriname & Mauritius & Japan \\
Côte d'Ivoire & Lebanon & Serbia Bosnia & Timor-Leste & Spain & Latvia \\
Croatia & Lesotho & Seychelles & & Trinidad \& Tobago & Luxembourg \\
Dominican Republic & Liberia & Sierra Leone & & Tunisia & Netherlands \\
Ecuador & Macedonia & Solomon Islands & & UK & New Zealand \\
Ecuador & Madagascar & South Africa & & US & Norway \\
Fiji & Malawi & Sri Lanka & & Uruguay & Portugal \\
Gambia & Malaysia & Tunisia & & Vanuatu & Slovenia \\
Georgia & Mali & Turkey & & South Korea \\
Ghana & Mexico & Ukraine & & Sweden \\
Guatemala & Moldova & & & Switzerland \\
& & & & Taiwan \\
\hline
\end{tabular}

Notes: The country distribution refers to 2018 and comprises all independent countries covered by V-Dem (v9). The distinctions are based on the competitive elections indicator from LIED and the electoral democracy index, the liberal component index, and the egalitarian component index from V-Dem.

0.89 on the V-Dem egalitarian component index identifies the egalitarian democracies. ${ }^{9}$ Table 1.4 shows the distribution of polities in 2018 on the four types of democracy, where members of higher-order categories are by definition also members of all less demanding categories. For example, all liberal democracies, such as Australia and Chile, also belong to the set of minimalist democracies.

The overview reveals that relatively few polities are classified as egalitarian democracies and that most of them are rich, Western European countries with long traditions of electoral contestation. In contrast, most third wave countries are only minimalist democracies or polyarchies. There are positive exceptions, though, such as the Baltic countries and some of the Asian Tigers. The country distribution indicates that there is a strong covariation between socio-economic development and type of democracy, but it does not say anything about the existence and direction of a causal relationship.

\section{CONCLUSION}

Dahl (1989, p. 2) once noted that 'a term that means anything means nothing. And so it has become with "democracy", which nowadays is not so much a term of restricted and specific meaning as a vague endorsement of a popular idea.' However, this situation did not make Dahl abstain from continuing to discuss and précis his own understanding of democracy - or 
to identify and account for real existing democracies for that matter. Although fundamental disagreements still exist about the correct definition of democracy, and even though some conceptions of democracy build on conflicting values, this chapter has shown that it is possible to order many particular understandings into more general clusters. Moreover, I have suggested approaches that can be helpful when trying to systematize the relationship between different conceptions, and I have argued that there is a set of minimum conditions that need to be included in any meaningful definition of democracy.

Related to the last point, it has been argued that researchers should avoid the inclusion of potential causes and consequences of democracy (such as rule of law, social equality, or a lively civil society) into the concept of democracy. The argument goes that this choice would solve interesting factual questions by definitional fiat. If, for instance, one is interested in the empirical association between economic equality and democracy, it would not be suitable to consider economic equality as a defining feature of democracy as this would generate a tautological relationship (Cheibub, Gandhi and Vreeland, 2010, p. 73; Przeworski et al., 2000, p. 33). Even though there are some limits to what features can meaningfully be constitutive of democracy, many of the arguments in favor of including attributes that go beyond contested elections are plausible considering the baseline values of political freedom and equality. When trying to disentangle theoretical and empirical relationships between democracy and some other variable, it can be valuable to carefully distinguish these phenomena. However, researchers also have the choice of focusing on the relationship between more particular elements of overarching concepts to avoid disturbing overlaps.

I make no claim to have offered the authoritative conceptualization of the seven traditions introduced in this chapter. My aim is a modest one of identifying some the most important and distinctive attributes associated with the most influential conceptions of democracy and thereby to provide some guidance for researchers and students interested in this issue. Others might suggest different ways to make sense of the complexity characterizing the field of democratic theory. If these attempts are transparent, coherent, and well justified, they are more than welcome.

Moreover, the conceptions of democracy presented here are not exhaustive. Some extant traditions have been neglected and new ones will probably be suggested in the future. The conceptualization of democracy will continue to be debated. Societal developments, intellectual innovations, and novel research questions sometimes call for a rethinking of our concepts. They are, after all, merely tools used for the higher purposes of precise communication and scientific progress, that is, the achievement of valid theoretical and empirical insights.

\section{NOTES}

1. Some scholars add control as a third dimension (e.g., Bühlmann et al., 2012; Lauth, 2004) but since control is merely considered as a means to safeguard equality and freedom, it should not have the same constitutive status.

2. This could be marked in the table by also adding the criteria mentioned in connection to electoral democracy to the list of criteria linked to all the other conceptions. However, I prefer not to do so here to avoid blurring the overview and to emphasize the distinct features. The overlap is obvious from the following discussions.

3. The description of the different conceptions of democracy is heavily inspired by - and partly overlapping with - some of my previous works on the topic, especially Coppedge et al. (2020, Ch. 2; see also Møller and Skaaning, 2011, 2013). 
4. That is, adequate and equal opportunities to discover and validate relevant information.

5. Dahl (1971, p. 3) originally conceived eight requirements. Later, he reduced them to seven (Dahl, 1989 , p. 221) and eventually to six.

6. Held (2006) identifies both a protective and a developmental version of liberalism. Here we focus on the former, because it represents what most scholars have in mind when referring to liberal democracy (see, e.g., Diamond, 1999; Fukuyama, 2014; Møller and Skaaning, 2011; O'Donnell, 2001; Zakaria, 2003).

7. Other works have also distinguished between different institutional configurations of democracies and their expected impact on inclusion and effectiveness (e.g., Gerring and Thacker, 2008; Powell, 1982; Tsebelis, 2002), but they have generally been less influential than Lijphart's work.

8. Note that since the ranking is mainly used for illustrative purposes, I do not utilize the confidence bounds associated with the V-Dem point estimates. Doing so would reveal that many of the differences are not statistically significant at conventional levels.

9. The cumulative ordering requires crisp distinctions on each level. This means that some valuable information is lost. In addition, although the thresholds are inspired by country distributions identified in previous studies (see Møller and Skaaning 2011, 2013), they are necessarily somewhat arbitrary since the V-Dem indices are continuous.

\section{REFERENCES}

Ake, Claude (2000). The Feasibility of Democracy in Africa. Dakar: CODESRIA.

Bagehot, Walter ([1867] 1963). The English Constitution. Ithaca, NY: Cornell University Press.

Barber, Benjamin (1984). Strong Democracy: Participatory Politics for a New Age. Berkeley, CA: University of California Press.

Beetham, David (1999). Democracy and Human Rights. Cambridge, UK: Polity Press.

Beetham, David (2004). 'Freedom as the foundation.' Journal of Democracy, 15(4), 1-75.

Beitz, Charles (1990). Political Equality. Princeton, NJ: Princeton University Press.

Bentham, Jeremy ([1776] 1988). A Fragment on Government. Cambridge, UK: Cambridge University Press.

Bernstein, Eduard ([1899] 1961). Evolutionary Socialism: A Criticism and Affirmation. New York: Schocken Books.

Bessette, James M. (1980). 'Deliberative democracy: the majority principle in republican government.' In Robert A. Goldwin and William A. Schambra (eds), How Democratic is the Constitution? Washington, DC: American Enterprise Institute, pp. 102-16.

Bohman, James (1998). 'The coming of age of deliberative democracy.' Journal of Political Philosophy, 6(4), 400-25.

Bühlmann, Marc, Wolfgang Merkel, Lisa Müller and Bernhard Weßels (2012). 'The democracy barometer: a new instrument to measure the quality of democracy and its potential for comparative research.' European Political Science, 11(4), 519-36.

Cartledge, Paul (2018). Democracy: A Life. Oxford: Oxford University Press.

Chambers, Simone (2003). 'Deliberative democratic theory.' Annual Review of Political Science, 6, 307-26.

Cheibub, José A., Jennifer Gandhi and James Vreeland (2010). 'Democracy and dictatorship revisited.' Public Choice, 143(1/2), 67-101.

Collier, David and Robert Adcock (1999). 'Democracy and dichotomies: a pragmatic approach to choices about concepts.' Annual Review of Political Science, 2, 537-65.

Collier, David, Fernando D. Hidalgo and Andra Olivia Maciuceanu (2006). 'Essentially contested contests: debates and applications.' Journal of Political Ideologies, 1(3), 211-46.

Collier, David and Steven Levitsky (1996). 'Democracy with adjectives: conceptual innovation in comparative research.' Working Paper No. 230, Helen Kellogg Institute for International Studies, University of Notre Dame, Indiana.

Collier, David and Steven Levitsky (1997). 'Democracy with adjectives: conceptual innovation in comparative research.' World Politics, 49(3), 430-51. 
Coppedge, Michael and John Gerring, with David Altman et al. (2011) 'Defining and measuring democracy: a new approach.' Perspectives on Politics, 9(2), 247-67.

Coppedge, Michael, John Gerring and Adam Glynn et al. (2020). Varieties of Democracy: Measuring Two Centuries of Political Change. New York: Cambridge University Press.

Cunningham, Frank (2002). Theories of Democracy: A Critical Discussion. Abingdon: Routledge.

Dahl, Robert A. (1971). Polyarchy: Participation and Opposition. New Haven, CT: Yale University Press.

Dahl, Robert A. (1982). Dilemmas of Pluralist Democracy: Autonomy vs. Control. New Haven, CT: Yale University Press.

Dahl, Robert A. (1985). A Preface to Economic Democracy. Cambridge, UK: Polity Press.

Dahl, Robert A. (1989). Democracy and Its Critics. New Haven, CT: Yale University Press.

Dahl, Robert A. (1998). On Democracy. New Haven, CT: Yale University Press.

Diamond, L. (1999). Developing Democracy: Toward Consolidation. Baltimore, MD: Johns Hopkins University Press.

Diamond, Larry (2002). 'Thinking about hybrid regimes.' Journal of Democracy, 13(2), 21-35.

Dryzek, John (2010). 'Rhetoric in democracy: a systemic appreciation.' Political Theory, 38(3), 319-39.

Dunn, John (2005). Setting the People Free: The Story of Democracy. London: Atlantic Books.

Elster, Jon (1998). Deliberative Democracy. New York: Cambridge University Press.

Fishkin, James S. (1991). Democracy and Deliberation: New Directions for Democratic Reform. New Haven, CT: Yale University Press.

Freeden, Michael (1978). The New Liberalism: An Ideology of Social Reform. Oxford: Clarendon Press.

Fukuyama, Francis (2014). Political Order and Political Decay: From the Industrial Revolution to the Globalization of Democracy. London: Profile Books.

Fuller, Lon L. (1969). The Morality of Law. New Haven, CT: Yale University Press.

Gallie, Walter B. (1956). 'Essentially contested concepts.' Proceedings of the Aristotelian Society, 56, 167-98.

Gerring, John, Daniel Pemstein and Svend-Erik Skaaning (2018). 'An ordinal, concept-driven approach to measurement: the lexical scale.' Sociological Methods \& Research. https://doi.org/10.1177/ 0049124118782531

Gerring, John and Strom Thacker (2008). A Centripetal Theory of Democratic Governance. New York: Cambridge University Press.

Gordon, Scott (1999). Controlling the State: Constitutionalism from Ancient Athens to Today. Cambridge, MA: Harvard University Press.

Gutmann, Amy and Dennis Thompson (1998). Democracy and Disagreement. Cambridge, MA: Belknap Press.

Habermas, Jürgen ([1981] 1987). The Theory of Communicative Action. Boston, MA: Beacon Press.

Habermas, Jürgen ([1992] 1996). Between Facts and Norms: Contributions to a Discourse Theory of Law and Democracy. Cambridge, MA: MIT Press.

Hamilton, Alexander, James Madison and John Jay ([1787/88] 1992). The Federalist Papers. Cutchogue, NY: Buccaneer Books.

Hansen, Mogens Herman (1989). 'Athenian democracy.' Classical Review, 39(1), 69-76.

Hansen, Mogens Herman (1991). The Athenian Democracy in the Age of Demosthenes: Structure, Principles, and Ideology. Oxford: Blackwell.

Held, David (2006). Models of Democracy. Cambridge, UK: Polity Press.

Heller, Hermann (1930). Recht und Staat in Geschichte und Gegenwart. Tübingen: J.C.B. Mohr.

Holmes, Stephen (1995). Passion and Constraint: On the Theory of Liberal Democracy. Chicago, IL: University of Chicago Press.

Kelsen, Hans (1920). Vom Wesen und Wert der Demokratie. Tübingen: J.C.B. Mohr.

Laclau, Ernesto and Chantal Mouffe (1985). Hegemony and Socialist Strategy: Towards A Radical Democratic Politics. London: Verso.

Lauth, Hans-Joachim (2004). Demokratie und Demokratiemessung: Eine konzeptionelle Grundlegung für den interkulturellen Vergleich. Wiesbaden: VS Verlag für Sozialwissenschaften.

Lenin, Vladimir I. ([1917] 2004). The State and the Revolution. Whitefish, MT: Kessinger Publishing.

Levitsky, Steven and Lucan Way (2010). Competitive Authoritarianism. New York: Cambridge University Press. 
Lijphart, A. (1999). Patterns of Democracy: Government Forms and Performance in Thirty-Six Countries. New Haven, CT: Yale University Press.

Lindblom, Charles E. (1977). Politics and Markets: The World's Political-Economic Systems. New York: Basic Books.

Luxemburg, Rosa ([1899] 2006). Reform or Revolution. Mineola, NY: Dover Press.

Macpherson, C.B. (1977). The Life and Times of Liberal Democracy. New York: Oxford University Press.

Mainwaring, Scott (2001). 'Two models of democracy.' Journal of Democracy, 12(3), 170-75.

Mansbridge, Jane (1983). Beyond Adversary Democracy. Chicago, IL: University of Chicago Press.

Marx, Karl ([1848] 1988). The Civil War in France. New York: International Publishers.

Merkel, Wolfgang (2004). 'Embedded and defective democracies.' Democratization, 11(1), 33-58.

Meyer, Thomas (2007). The Theory of Social Democracy. Cambridge, UK: Polity Press.

Mill, John Stuart ([1861] 1993). 'Considerations on representative government.' In John Stuart Mill, Utilitarianism, On Liberty, Considerations on Representative Government, Remarks on Bentham's Philosophy. London: Dent, pp. 188-428.

Møller, Jørgen and Svend-Erik Skaaning (2011). Requisites of Democracy: Conceptualization, Measurement, and Explanation. Abingdon: Routledge.

Møller, Jørgen and Svend-Erik Skaaning (2013). Democracy and Democratization in Comparative Perspective: Conceptions, Conjunctures, Causes, and Consequences. Abingdon: Routledge.

Møller, Jørgen and Svend-Erik Skaaning (2014). The Rule of Law: Definitions, Measures, Patterns, and Causes. Basingstoke: Palgrave Macmillan.

Montesquieu, Charles de Secondat ([1748] 1989). Spirit of the Laws. Cambridge, UK: Cambridge University Press.

Morse, Yonatan (2012). 'The era of electoral authoritarianism.' World Politics, 64(1), 161-98.

Munck, Gerardo L. (2016). 'What is democracy? A reconceptualization of the quality of democracy.' Democratization, 23(1), 1-26.

Naess, Arne, Jens Christophersen and Kjell Kvalo (1956). Democracy, Ideology and Objectivity: Studies in the Semantics and Cognitive Analysis of an Ideological Controversy. Oslo: Universitetsforlaget.

Nussbaum, Martha C. (2011). Creating Capabilities: The Human Development Approach. Cambridge, MA: Harvard University Press.

Ober, Joshia (1989). Mass and Elite in Democratic Athens: Rhetoric, Ideology, and the Power of the People. Princeton, NJ: Princeton University Press.

O'Donnell, Guillermo (2001). 'Democracy, law, and comparative politics.' Studies in Comparative International Development, 36(1), 7-36.

O'Donnell, Guillermo (2004). 'Why the rule of law matters.' Journal of Democracy, 15(4), 32-46.

O'Donnell, Guillermo (2007). Dissonances: Democratic Critiques of Democracy. Notre Dame, IN: University of Notre Dame Press.

Offe, Claus and Ulrich Preuss (1991). 'Democratic institutions and moral resources.' In David Held (ed.), Political Theory Today. Palo Alto, CA: Stanford University Press, pp. 141-71.

Orwell, George (1962). 'Politics and the English language.' In George Orwell, Inside the Whale and Other Essays. Harmondsworth: Penguin, pp. 143-57.

Paine, Thomas ([1791] 1996). Rights of Man. Ware: Wordsworth.

Pateman, Carole (1976). Participation and Democratic Theory. Cambridge, UK: Cambridge University Press.

Powell, G. Bingham (1982). Contemporary Democracies: Participation, Stability, and Violence. Cambridge, MA: Harvard University Press.

Przeworski, Adam, Michael E. Alvarez, José Cheibub and Fernando Limongi (2000). Democracy and Development: Political Institutions and Well-Being in the World, 1950-1990. New York: Cambridge University Press.

Raz, Joseph (1979). The Authority of Law: Essays on Law and Morality. Oxford: Clarendon Press.

Ross, Alf (1952). Why Democracy? Cambridge, MA: Harvard University Press.

Rousseau, Jean-Jacques ([1762] 1984). Of the Social Contract; or, Principles of Political Right and Discourse on Political Economy. Trans. Charles M. Sherover. New York: Harper \& Row.

Sartori, Giovanni (1970). 'Concept misformation in comparative politics.' American Political Science Review, 64(4), 1033-53. 


\section{Research handbook on democracy and development}

Sartori, Giovanni (1987). The Theory of Democracy Revisited. Chatham, NJ: Chatham House.

Saward, Michael (1998). The Terms of Democracy. Cambridge, UK: Polity Press.

Schedler, Andreas (2013). The Politics of Uncertainty: Sustaining and Subverting Electoral Authoritarianism. Oxford: Oxford University Press.

Schumpeter, Joseph A. ([1942] 1974). Capitalism, Socialism and Democracy. London: Unwin University Books.

Seeberg, Merete B. (2018). State Capacity, Economic Control, and Authoritarian Elections. Abingdon: Routledge.

Sen, Amartya (2001). Development as Freedom. Oxford and New York: Oxford University Press.

Skaaning, Svend-Erik, John Gerring and Henrikas Bartusevičius (2015). 'A lexical index of electoral democracy.' Comparative Political Studies, 48(12), 1491-525.

Tsebelis, George (2002). Veto Players. Princeton, NJ: Princeton University Press.

Vile, M. J. C. (1998). Constitutionalism and the Separation of Powers. Indianapolis, IN: Liberty Fund.

Wolfe, Joel (1986). 'Varieties of participatory democracy and democratic theory.' Political Science Reviewer, 16, 1-38.

Zakaria, Fareed (2003). The Future of Freedom: Illiberal Democracy at Home and Abroad. New York: W.W. Norton \& Company. 